
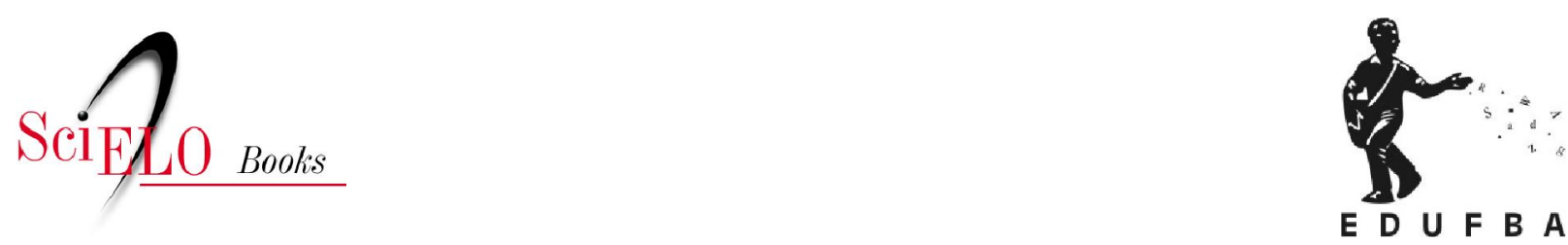

\title{
Os contendores
}

\author{
Silvia Noronha Sarmento
}

\section{SciELO Books / SciELO Livros / SciELO Libros}

SARMENTO, S. N. Os contendores. In: A raposa e a águia: J.J. Seabra e Rui Barbosa na política baiana da primeira república [online]. Salvador: EDUFBA, 2011, pp. 25-54. ISBN 978-85-232-11530 . Available from: doi: $10.7476 / 9788523211530.003$. Also available in ePUB from: http://books.scielo.org/id/ykf8q/epub/sarmento-9788523211530.epub.

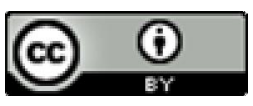

All the contents of this work, except where otherwise noted, is licensed under a Creative Commons Attribution $\underline{4.0 \text { International license. }}$

Todo o conteúdo deste trabalho, exceto quando houver ressalva, é publicado sob a licença Creative Commons Atribição 4.0.

Todo el contenido de esta obra, excepto donde se indique lo contrario, está bajo licencia de la licencia $\underline{\text { Creative }}$ Commons Reconocimento 4.0. 


\section{Ar}

OS CONTENDORES

\section{Origens familiares, vínculos sociais, formação acadêmica}

Menos de seis anos separam o nascimento de Rui Barbosa (5 nov. 1849) do de José Joaquim Seabra (21 ago. 1855). ${ }^{1}$ Ambos nasceram em Salvador, em uma época em que a província da Bahia passava por importantes transformações. A lavoura canavieira do Recôncavo, antigo sustentáculo da economia colonial, enfrentava uma crise que se mostraria irreversível. Ao mesmo tempo, expandia-se a lavoura de café em São Paulo, assentada em bases produtivas mais adequadas ao contexto mundial. Não se tratava apenas de mais um produto de exportação. O café dinamizou a economia paulista, viabilizou a concentração de capital, a urbanização e a industrialização, contribuindo para consolidar definitivamente a mudança do eixo econômico do país para o centro-sul.

Para melhor dimensionar o impacto dessa transformação, observe-se que, em 1820, o açúcar e o algodão ainda eram os principais produtos

${ }_{1}$ Rui Barbosa nasceu no centro de Salvador, na rua que hoje leva seu nome. Seabra nasceu na Cidade Baixa, no bairro dos Mares. As informações biográficas foram extraídas das obras de Luís Viana Filho e João Felipe Gonçalves (para Rui), Francisco Borges de Barros, Edilton Meireles dos Santos e Renato Berbert de Castro (para Seabra), listadas nas referências bibliográficas. 
da pauta comercial brasileira, com o café em terceiro lugar. Ao fim do século, na década de 1890, o café já se isolara em primeiro lugar, respondendo por mais de $65 \%$ do valor das exportações, percentual muito superior ao do açúcar (6,2\%), fumo (1,9\%) e cacau (1,3\%). Considerando que açúcar, fumo e cacau eram os principais produtos da Bahia, e que a lavoura cafeeira já estava concentrada principalmente em São Paulo, pode-se avaliar o balanço de poder econômico entre as duas províncias no período. A relação pode ser estendida para o conjunto do país, configurando um desequilíbrio regional Norte-Sul que se intensificaria nas décadas seguintes. (FUNDAÇÃo CENTRO DE PESQUISA E ESTUdOS, 1980; SAMPAIO, 1977)

A mudança na centralidade econômica, no entanto, não teve correspondência imediata no plano político. A Bahia ainda mantinha, no Império, uma posição política de grande relevo. Entre 1822 e 1889, foi a província com maior participação nos gabinetes ministeriais $(19,16 \%$ dos ministros eram baianos), superando o Rio de Janeiro, sede da Corte (18,27\%), Minas Gerais (13,25\%), Pernambuco (10,05\%), São Paulo (10,04\%) e Rio Grande do Sul (6,39\%). A presença dos baianos evidenciava-se tanto nos gabinetes liberais como nos conservadores, e era marcante nos postos mais cobiçados, como a presidência do Conselho de Ministros. Dos 30 presidentes do Conselho de Ministros nomeados de 1847, quando o cargo foi criado, ao fim do Império, 11 (mais de um terço) eram baianos. (CARVALHO, 2006) ${ }^{2}$

Os baianos mais destacados eram provenientes, em sua maioria, da elite agrária tradicional, que vinha perdendo a preeminência econômica tanto no nível nacional, para o café, como no provincial, para o comércio. Com suas qualificações de estirpe e longa experiência no poder, os barões, viscondes e conselheiros baianos sustentavam um "poder

\footnotetext{
2 A grande proporção de baianos é explicada, em parte, pelo maior índice de educação superior na província, em relação às demais. (CARVALHO, 2006) Alguns autores também creditam a prevalência dos baianos na política imperial a seu perfil conservador. Essa ideia é expressa por Oliveira Viana (2002, p. 1113), para quem D. Pedro II se cercava de "políticos extremamente reverenciais ao trono", escolhendo os baianos por essas qualidades: "Inteligentes, hábeis, maneirosos, cheios de vivacidade, graça e ironia, um tanto plásticos, são os baianos mais capazes, com efeito, do que quaisquer outros, de compreender e realizar os intuitos íntimos da política imperial, que é estabelecer um absolutismo de fato sob a máscara do regime parlamentar".
}

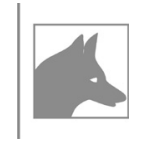


político residual" (SAMPAIO , 1998), visceralmente articulado aos destinos do regime monárquico. Homens como o barão de Cotegipe, o visconde do Rio Branco, o conselheiro Saraiva, o conselheiro Dantas, entre outros, integravam-se em uma elite nacional com forte tendência à coesão e à homogeneidade, que reforçava seus laços através da formação acadêmica (predomínio de bacharéis em Direito), experiências profissionais (ingresso na advocacia ou magistratura, progressão em cargos públicos), circulação geográfica, entre outros fatores. (CARVALHO, 2006)

Foi nesse contexto que Rui Barbosa e Seabra nasceram, cresceram, foram educados e iniciaram suas trajetórias. Nascidos em famílias urbanas, sem vínculo com a terra, os dois jovens baianos se aliaram a segmentos sociais profundamente vinculados aos grandes proprietários. Rui e Seabra conviveram com os fazendeiros e seus filhos no ambiente escolar (desde os estudos preparatórios até o curso superior), na vida social (em cafés, livrarias, teatros e outros espaços de socialização ocupados por políticos e intelectuais), na vida familiar (através de vínculos de parentesco e relações de amizade). Era através do estabelecimento de uma rede de contatos com a elite tradicional da província que jovens como eles tinham possibilidade de ingressar no restrito mundo da política profissional.

Rui Barbosa era filho do ramo empobrecido de uma família bem relacionada. Seu pai, João José Barbosa de Oliveira, havia sido deputado provincial e geral, mas encontrava-se em má situação econômica e afastado da política na época de seu nascimento. Segundo Luís Viana Filho (2008, p. 41), a certa altura, era a esposa quem manejava o sustento da casa, a partir da produção de doces pelos escravos domésticos. Alguns anos depois, a família manteve uma olaria no subúrbio de Plataforma. A mãe de Rui, quando solteira Maria Adélia Barbosa de Almeida, era prima do marido e irmã de Luís Antônio Barbosa de Almeida, político em Salvador. Os pais de Rui eram parentes do conselheiro Albino José Barbosa de Oliveira, considerado o "patriarca" da família. ${ }^{3}$

3 José Murilo de Carvalho (2006, p. 160) informa sobre o conselheiro Albino: "brasileiro de 
As informações sobre as origens familiares de Seabra são menos conhecidas. Sabe-se que seu pai, que também se chamava José Joaquim Seabra, era funcionário da Alfândega da Bahia, cargo provavelmente obtido através de contatos sociais ou políticos. O nome do pai de Seabra aparece em uma lista de acionistas da primeira ferrovia que se construiu na província, a Bahia and São Francisco Railway. (SOUZA, 2007, p. 16) Com 30 ações, das 5 mil colocadas à venda em Salvador em 1858 (a maior parte do capital da ferrovia era negociada em Londres), ele era provavelmente apenas um dos pequenos acionistas da companhia. A mãe de Seabra, que tinha o nome de solteira Leopoldina Alves Barbosa, era irmã do contra-almirante Manuel José Alves Barbosa, futuro ministro da Marinha na República.

O biógrafo seabrista Francisco Borges de Barros (1931) diz que Seabra foi um "estudante pobre" em Recife, o que sugere uma origem familiar socialmente desfavorável. Isso não é inteiramente verdadeiro. Embora desprovidos de fortuna, e, eventualmente, em dificuldades financeiras, tanto Seabra como Rui dispunham de certo capital social, como sugere Bourdieu (2005), ou seja, tinham relações de parentesco ou afinidade com pessoas dos altos escalões sociais e políticos. Os dados disponíveis indicam que os contatos de Seabra eram mais restritos do que os de Rui. De qualquer forma, para ampliar suas credenciais de acesso, ambos deveriam seguir a trilha conhecida por todos: formação superior, preferencialmente em Direito, atuação na advocacia e no jornalismo, associação com um chefe estabelecido.

Após estudar no conceituado ginásio de Abílio César Borges, onde foi colega de Castro Alves, Rui ingressou na Faculdade de Direito de Recife em 1866. Transferiu-se no meio do curso para a outra única faculdade de Direito existente no país em São Paulo. A transferência de alunos entre

origens modestas, chegou ao topo da carreira à sombra de um casamento que o ligou às mais ricas famílias e aos mais importantes políticos do Rio de Janeiro e de São Paulo, tanto liberais como conservadores. O casamento não só o fez dono de fazendas de café, como também lhe facilitou promoções e transferências vantajosas".

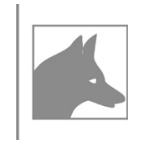


os dois cursos não era incomum e, no caso de Rui, deveu-se principalmente à indignação por uma nota que considerou injusta ${ }^{4}$. Durante o curso, concluído em 1870, Rui atuou no jornalismo, envolveu-se com a maçonaria e com o movimento abolicionista. Em São Paulo, foi novamente colega de Castro Alves, do futuro barão do Rio Branco e de dois futuros presidentes da República, Afonso Pena e Rodrigues Alves, entre outros.

Seabra fez os estudos preparatórios nos colégios de Guilherme Rebello e de Urbano Monte, em Salvador. Não chegou a ser colega de Rui na faculdade de Direito de Recife, na qual ingressou em 1873. Permaneceu nessa faculdade, não apenas durante o curso, mas também como professor. Quanto ao desempenho acadêmico de Seabra, vários biógrafos reproduzem a história de que ele teria sido o primeiro aluno aprovado com distinção em todos os anos do curso, sendo por isso agraciado com um prêmio. (BARROS, 1931; SANTOS, E., 1990) Essa história foi narrada pelo próprio Seabra, ao fim da vida, em entrevista à revista Diretrizes (1942). Dados obtidos por Renato Berbert de Castro (1990) no acervo da faculdade revelam, porém, que ele não obteve distinção no primeiro e no terceiro anos do curso, portanto não teve distinção em todos os anos. Por outro lado, esse autor encontrou referências a um prêmio concedido ao aluno Seabra em 1877, ano de sua formatura, mas não esclareceu sua motivação.

Como Rui, Seabra participou ativamente do ambiente acadêmico à sua volta, e também da vida boêmia pernambucana. Imediatamente após a formatura, foi nomeado promotor público em Salvador, o que sugere bons contatos sociais e políticos. Em 1878, casou-se com Amélia Benvinda de Freitas, filha do Dr. José Antônio de Freitas, em cerimônia celebrada pelo arcebispo da Bahia, D. Joaquim Gonçalves de Azevedo, tendo como testemunhas o barão Homem de Melo, então presidente da província, e José Luís de Almeida Couto, que governaria a Bahia por dois

\footnotetext{
4 Rui teve vários infortúnios nos primeiros anos do curso: divergências entre seu pai e o tio Luís Antônio, a morte da mãe, e sérios problemas de saúde ("congestão cerebral"). A nota medíocre dada por um professor, por critérios que considerou injustos, foi a gota d'água para a transferência para São Paulo. (VIANA FILHO, 2008, p. 56)
} 
períodos. (CASTRO, 1990) O casamento era uma forma importante de firmar prestígio social, e a presença daqueles homens ilustres evidencia, mais uma vez, as conexões de Seabra com o alto escalão da política provincial.

Rui Barbosa casou-se, em 1876, com Maria Augusta Viana Bandeira, namoro estimulado pelo conselheiro Souto, amigo de ambos. Os biógrafos costumam salientar o fato de que a noiva não tinha fortuna, era uma "moça pobre", filha de "modesto funcionário público", como a garantir que Rui, contrariando o comportamento comum à época, casou-se por amor, não por interesse político ou financeiro. Deixando de lado questões amorosas, afirmar que Maria Augusta era "pobre" pode levar a uma compreensão equivocada de sua posição social. Ela vinha de família tradicional, com parentes bem colocados na sociedade, embora sua situação financeira fosse apenas remediada, como a do noivo ${ }^{5}$.

Antes do casamento, Rui foi para o Rio de Janeiro para tentar acumular algum capital, pois seu pai faleceu deixando grande dívida. Mais uma vez, o apoio dos amigos importantes foi essencial: o conselheiro Souto emprestou-lhe dinheiro para a viagem e o conselheiro Dantas deu-lhe cartas de apresentação para políticos na Corte. Nos primeiros tempos, Rui ficou instalado em um cômodo do palacete do conselheiro Albino, seu parente. (VIANA FILHO, 2008, p. 113-115) Mesmo para um jovem de grande talento, como Rui, seria provavelmente impossível conquistar um espaço na política, advocacia ou jornalismo - os três campos eram, muitas vezes, sobrepostos - sem essas recomendações e apoios.

A inserção de Rui na política imperial foi mais bem sucedida do que a de Seabra. Dentre seus contatos no mundo político, o mais importante era o conselheiro Manuel de Sousa Dantas, chefe do Partido Liberal na Bahia e antigo amigo de seu pai. A relação de Rui com

\footnotetext{
Segundo Luís Viana Filho (2008, p. 108), Maria Augusta pertencia à família Ferreira Bandeira. Tinha parentes ricos, alguns com títulos de nobreza, mas seu pai descendia da parte "pobre" da família. Ela permaneceu casada com Rui por toda a vida. Com a ascensão social do marido, tornou-se referência de elegância no Rio de Janeiro. O casamento de Seabra não teve desfecho semelhante. Em uma atitude pouco comum, o casal Amélia e Seabra se separou, embora não oficialmente. Um dos irmãos de Amélia, José Augusto de Freitas, era aliado de Seabra no início da carreira, tornando-se mais tarde seu adversário ferrenho.
}

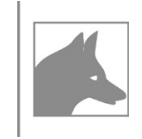


o conselheiro Dantas e seu filho Rodolfo era quase familiar. Em 1873, por exemplo, quando eles foram à França para tratamento de saúde, o enfermiço Rui foi convidado a acompanhá-los. Era sua primeira visita à Europa e ele se encantou com Paris. (VIANA FILHO, 2008, p. 88, 93) $\mathrm{Na}$ firma de advocacia dos Dantas, em Salvador, Rui iniciou sua atividade profissional. Trabalhou também no jornal da família, o Diário da Bahia, porta-voz do Partido Liberal na província. Em 1878, amparado nesses apoios, obteve seu primeiro mandato de deputado provincial na Bahia e, no ano seguinte, foi promovido a deputado geral, sempre pelo Partido Liberal, então no poder.

De volta à Corte, o deputado Rui não demorou a chamar a atenção, com sua habilidade para o debate e a capacidade de enfrentar oradores famosos. Destacou-se, especialmente, na redação e defesa do chamado Projeto Dantas (1884), proposto no gabinete do seu padrinho político. Esse projeto previa a emancipação dos escravos maiores de 60 anos e obrigava os senhores a declarar a procedência dos cativos, em uma tentativa de fazer valer a Lei Feijó, de $1831^{6}$. Segundo João Felipe Gonçalves (2000b, p. 43), a proposta era considerada tímida por muitos abolicionistas, mas ameaçadora pelos escravocratas, que chegaram a chamar Rui de "comunista" na Câmara dos Deputados. A reação negativa, somada a incompatibilidades no Partido Liberal baiano, inclusive com o tio Luís Antônio, renderam a Rui uma derrota na tentativa de reeleição ao fim de 1884. Paradoxalmente, no mesmo ano, havia recebido de D. Pedro II o título de conselheiro.

As dificuldades se intensificaram nos anos seguintes, e Rui não conseguiu mais eleger-se até o fim do Império. Sofreu três derrotas seguidas: em janeiro de 1886, junho de 1888 e agosto de 1889. Para Gonçalves (2000b, p. 48), formou-se um ciclo: o fechamento dos canais políticos levava Rui

\footnotetext{
6 A Lei Feijó foi uma tentativa de extinguir o tráfico negreiro. Ela declarava livres os africanos trazidos a partir de então para o Brasil. Se, em 1884, os senhores fossem obrigados a declarar a procedência dos seus cativos, como queriam Rui e Dantas, ficaria provado que grande parte deles era legalmente livre, pois havia chegado ao país depois de 1831. Por isso, a proposta era considerada perigosa pelos senhores. Para os que desejavam a abolição imediata, porém, a medida era apenas mais um passo gradual no longo processo de extinção da escravidão no Brasil.
} 
a radicalizar suas críticas, o que contribuía para reduzir suas chances eleitorais, já diminuídas pelo fato de o Partido Liberal estar fora do poder. Em agosto de 1889, com o retorno do partido (gabinete do visconde de Ouro Preto), Rui viu a possibilidade, não só de voltar ao Parlamento, mas, ainda, de alcançar um cargo de ministro. Porém, seus planos foram totalmente frustrados. Segundo a versão do próprio Rui, ele teve que recusar o convite para o ministério porque Ouro Preto não garantiu a implantação do federalismo, sua bandeira na época. Outros relatos indicam que ele não foi convidado para ser ministro, o que, diante da expectativa criada, equivalia a uma exclusão acintosa. Para piorar, sequer foi incluído na chapa baiana de candidatos liberais para o Parlamento, apesar dos esforços do conselheiro Dantas. Seu partido havia retornado ao poder, mas as perspectivas políticas de Rui eram mais sombrias do que nunca.

A retórica agressiva que vinha adotando, e que lhe causava prejuízos políticos, impulsionava, por outro lado, sua carreira jornalística. Na imprensa, Rui atuava através de "campanhas", ou seja, dedicava toda sua atenção a um determinado tema por um período, assumia uma posição e colocava seu talento a serviço da polêmica. A campanha que desencadeou no Diário de Notícias (RJ) contra o gabinete liberal de Ouro Preto é considerada um dos pontos altos de sua carreira jornalística. Até então, o monarquista Rui nunca havia direcionado suas críticas ao regime em si. Em 1889, admitiu, pela primeira vez, a adesão à República, caso a monarquia não implantasse o federalismo. Dessa forma, aproximou-se dos republicanos. Convidado, poucos dias antes, para participar da conspiração que derrubou a monarquia, Rui se tornou, após o 15 de novembro, uma das figuras centrais do novo regime.

O percurso de Seabra na política imperial foi bem diverso. Após a formatura, como já dito, ele foi nomeado promotor em Salvador, mas não se demorou no cargo. Logo, voltou a Recife para estudar por mais um ano, a fim de obter o grau de doutor. Em 1879, participou de um concurso para professor substituto que ficou famoso, referido por seus biógrafos 
como exemplar, não só de sua capacidade intelectual, como também de sua ousadia ${ }^{7}$. Convencido de que havia sido o melhor candidato, Seabra não se conformou com o terceiro lugar. Foi ao Rio de Janeiro para, em meio à audiência pública semanal do imperador Pedro II, pedir a revisão do resultado. Com o processo deferido a seu favor, foi empossado como professor substituto em 1880. Tornou-se catedrático seis anos depois. Além de prestigiosa, a cátedra deu a Seabra uma fonte de renda estável, que o sustentaria nos revezes da política. Mesmo após se afastar da sala de aula, ele continuou ligado à faculdade e recebendo os proventos durante toda a vida.

Estabelecido como professor e advogado em Recife, o jovem Seabra buscava uma oportunidade de ingressar na política. Escreveu cartas a alguns chefes do Partido Conservador baiano, como o conselheiro Saraiva, visconde de Paranaguá, barão de Cotegipe, entre outros, pedindo para ser incluído na chapa de candidatos do partido, sem sucesso. (CASTRO, 1990) Em agosto de 1889, após ser novamente excluído, resolveu concorrer como candidato avulso, naquela que seria a última eleição do Império. Proferiu dez conferências públicas em diversos bairros de Salvador - como Rui, sua principal bandeira era o federalismo - mas foi derrotado. $\mathrm{O}$ acesso ao sistema político parecia fechado para Seabra, pois ele não conseguia ser incluído na chapa dos partidos oficiais, nem se eleger de forma independente.

Em meio à efervescência da instalação da República, sua sorte mudou. Monarquista até então, a ponto de ter participado de uma homenagem ao Conde D’Eu em Recife ainda em 1889, Seabra aceitou sem problemas o novo regime. Quatro dias após a proclamação, já assinava na faculdade uma moção de apoio à República. Em 1890, proferiu "conferências republicanas" no interior da Bahia, em campanha por uma vaga na nova Assembleia Constituinte. Sua conversão não foi bem aceita por todos: em Vila Nova (atual Senhor do Bonfim), ele foi hostilizado por engenhei-

7 Esse concurso é narrado com diferentes nuances heroicas pelos biógrafos seabristas (BARROS, 1931; MORAIS FILHO, 1905) e pelo próprio Seabra, em entrevista à revista Diretrizes (1942). A versão aqui registrada é baseada no relato de Renato Berbert de Castro (1990). 
ros da ferrovia que duvidavam de suas convicções republicanas, mas foi defendido por José Gonçalves da Silva, chefe local e futuro governador da Bahia. Pela forma como foi recebido nessas cidades, com filarmônica e festas, Seabra mostrava já ter algum contato com potentados locais, juízes ou promotores. $\mathrm{Na}$ primeira eleição da República, conseguiu o que nunca havia obtido no Império: em fins de 1890, embarcava para o Rio de Janeiro para tomar posse como deputado federal. (CASTRO, 1990)

$\mathrm{O}$ ingresso de Seabra na nascente política republicana parece ter sido facilitado pela dificuldade com que a elite baiana, profundamente ligada à monarquia, recebeu a mudança de regime. Na Bahia, o movimento republicano nunca alcançou a dimensão que teve em São Paulo, onde os ideais de liberalismo e federalismo atraíam cafeicultores interessados em maior autonomia para a província e seus negócios. Ao contrário, a República trazia para as elites baianas a perspectiva de redução do poder político e de graves prejuízos econômicos: no caso dos barões do açúcar, a possibilidade de suspensão de benefícios fiscais concedidos ao fim do Império. (SAMPAIO, 1998) Assim, na Bahia, o movimento republicano atraiu, principalmente, elementos não integrados ao sistema político provincial, como estudantes de Medicina e alguns professores. (ARAÚJO, 1992) Os chefes estabelecidos mantiveram-se fiéis ao trono enquanto puderam, e a Bahia foi a última província a aderir oficialmente ao novo regime.

\section{Referências culturais: tradição e inovação}

Rui Barbosa e José Joaquim Seabra circulavam no mesmo universo social. Ambos nasceram, foram educados e começaram a atuar profissional e politicamente ainda no Império. Rui tinha 40 anos de idade na transição republicana, e Seabra, 34. Eram homens adultos, que conviveram plenamente com a sociedade brasileira da segunda metade do século $\mathrm{XIX}$, com seus valores, normas de conduta e hierarquias, inclusive com 
o estatuto da escravidão. Ambos vivenciaram essa realidade a partir de uma posição inicial bem semelhante: eram baianos de Salvador, oriundos de famílias urbanas, sem terras ou grandes fortunas, possuidores de escravos domésticos, dotados de bons vínculos sociais, formados em Direito e dispostos a participar ativamente do sistema político imperial ${ }^{8}$.

No entanto, quando Rui e Seabra iniciaram suas vidas adultas (pode-se tomar como marco o ingresso no ensino superior, respectivamente em 1866 e 1873), o sistema imperial enfrentava uma profunda crise. Mudanças estruturais na sociedade brasileira, inerentes ao próprio processo de declínio do modelo escravista e de inserção no novo panorama mundial, aliadas à conjuntura política nacional e à difusão de certas doutrinas estrangeiras, deram origem a um movimento de contestação às bases da ordem monárquica.

Associações abolicionistas, republicanas, positivistas, federalistas, entre outras, multiplicaram-se pelo país nas décadas de 1870 e 1880 . Eram formadas, em sua maioria, por jovens letrados que não estavam encontrando espaços de atuação no regime. Como analisa Ângela Alonso (2002), em reação ao sistema que os empurrava para a margem, esses jovens buscaram subsídios para contestar o regime e suas tradições - daí o grande sucesso de certas teorias que se difundiram nessa época, como o positivismo, o evolucionismo, o darwinismo social, entre outras. Elas traziam, apesar de suas especificidades, a perspectiva de uma sociedade moderna, racional, científica, livre das amarras da velha ordem saquarema.

Rui Barbosa e Seabra eram jovens sem futuro garantido, já que não possuíam recursos próprios. Ambos tiveram dificuldades de inserção na política imperial. Encaixavam-se, pois, no perfil da Geração de 1870, como os contestadores ficaram coletivamente conhecidos. Porém, a relação dos dois baianos com esses grupos teve características distintas.

8 Rui Barbosa alforriou sua última escrava doméstica (a "crioula” Lia, herdada dos pais) em $1^{\circ}$ de junho de 1884 , cinco dias antes da posse do gabinete Dantas, que viria a tratar da questão da escravidão. (VIANA FILHO, 2008, p. 203) Quanto a Seabra, os dados são sempre incompletos, mas sabe-se que possuía ao menos uma escrava doméstica, chamada Paulina, em 1883, conforme registros de embarque citados por Renato Berbert de Castro (1990). 
Rui era um dos membros mais destacados de uma dissidência do Partido Liberal conhecida como os "novos liberais". Esse grupo era formado majoritariamente por descendentes e apadrinhados de chefes estabelecidos do Partido Liberal, que amargavam as dificuldades de entrar na política em uma quadra de domínio do Partido Conservador (o próprio Rui demorou oito anos, depois da formatura, para conseguir seu primeiro mandato). Era uma situação diferente, por exemplo, da vivida pelos jovens das escolas técnicas, filhos de famílias de menores recursos e virtualmente excluídos da política imperial até então. No caso dos "novos liberais", a marginalização era mais branda e temporária. Por isso mesmo, esse foi o único grupo dos contestadores de 1870 que permaneceu monarquista. Sem aderir ao republicanismo, os "novos liberais" exigiam urgência nas reformas que levariam o Brasil ao nível dos países civilizados. A extinção da escravidão era considerada a principal medida nesse sentido. (ALONSO, 2002)

Nas primeiras décadas do século XIX, conforme Alfredo Bosi (1988), a concepção predominante do liberalismo imperial, não só admitia a escravidão, como ainda usava princípios do laissez-faire econômico para justificá-la: defendia-se a liberdade de ter escravos e a não interferência do Estado nesses assuntos. Ao fim do século, o quadro se alterou. Os "novos liberais" não estavam dispostos a aceitar o que consideravam uma incômoda e vergonhosa evidência do nosso atraso colonial. $\mathrm{Na}$ palavra autorizada de Joaquim Nabuco (2008, p. 51), "o sentimento de ser a última nação de escravos humilhava a nossa altivez e emulação de país novo". Ou, como analisa Bosi (1988, p. 31): “o conteúdo concreto da legitimidade, que é o coração dos valores de uma ideologia política, tinha mudado. E o motor dessa transformação fora o ideal civilizado do trabalho livre; não ainda sua necessidade absoluta e imediata, mas o seu valor".

Não admira que muitos desses "novos liberais" tenham se engajado no movimento abolicionista, muito impulsionado no período. É preciso observar, porém, que esse engajamento não implicava no apagamen- 
to de suas referências sociais. Sendo, em sua maioria, bacharéis brancos de certa posição, eles tinham uma longa convivência com a escravidão, como senhores. Tendiam, assim, a enfrentar a questão a partir da perspectiva senhorial, mesmo quando lutavam pela abolição. $\mathrm{O}$ ideal que os animava era uma sociedade civilizada que protegesse os humildes, não a dissolução radical dos vínculos patriarcais e da ordem constituída. "Os abolicionistas brasileiros inspiravam-se em exemplos científicos ou em noções liberais herdadas dos filósofos iluministas para projetar uma sociedade harmoniosa, porém tão hierárquica e desigual quanto a cultura monárquica que eles respiravam a cada dia”. (AZEVEDO, 1995/1996, p. 102)

Não se pretenderá, aqui, fazer uma análise do abolicionismo de Rui Barbosa, tema já abordado por outros autores. É certo que seu abolicionismo carregava as marcas de sua posição social e de suas vinculações políticas, bem como dos seus ideais humanistas e liberais, o que resultava em posições complexas e, eventualmente, contraditórias. Um exemplo é sua abordagem do papel que os escravos desempenharam na campanha abolicionista. Em alguns textos de 1889 (BARBOSA, 1889, v. 16, t. 2), preocupado em evitar que a abolição se convertesse em um perigo para a estabilidade social, Rui convocou os homens esclarecidos a conduzirem a "raça emancipada" e a "raça emancipadora" à harmonia. (ALBUQUERQUE, 2009) Nota-se, na própria construção verbal, a passividade atribuída, não só aos escravos, mas aos negros em geral (a "raça emancipada"). Porém, em outros textos (BARBOSA, 1889, v. 16, t. 1, p. 33), Rui pôs em relevo o protagonismo dos cativos, em contraponto aos que exaltavam a ação do governo imperial na abolição. Contra o discurso da princesa "redentora", ele destacou o papel ativo dos escravos, através das fugas em massa, e dos soldados do Exército, que se recusaram a recapturá-los.

Seabra também se declarava abolicionista, embora sua postura fosse mais moderada do que a de Rui. Para entender sua posição nessa questão, porém, é preciso antes verificar como ele se situava no cenário agitado dos últimos anos do Império. 
Apesar dos dados biográficos incompletos, parece certo que Seabra não herdou um patrimônio político semelhante ao de Rui, que era ligado por antigos laços de família ao Partido Liberal. Sem estar vinculado a nenhum dos partidos e desejoso de ingressar na política, Seabra tentou entrar na agremiação que oferecia maiores probabilidades de ascensão no momento, isto é, no Partido Conservador. Os dados de Renato Berbert de Castro (1990) indicam que ele buscou se aproximar dos chefes conservadores, tanto em Pernambuco como na Bahia. Mesmo na política interna da faculdade de Recife, a aproximação dos conservadores era mais proveitosa: entre 1876 e 1887, época em que Seabra estava concluindo seus estudos e iniciando o magistério, a faculdade foi dirigida pelo senador conservador João Alfredo de Oliveira.

Em 1884, em defesa de um chefe conservador, o conselheiro Machado Portela (professor e ex-diretor da faculdade), Seabra chegou a travar uma polêmica com Joaquim Nabuco. Ocorreu que, em uma conferência, Nabuco disse que o Partido Conservador era escravocrata porque estava adiando a abolição, citando nominalmente Machado Portela. Seabra interrompeu o orador para defender o conselheiro e o partido, sob as vaias da plateia. No dia seguinte, interpelado por um cavalheiro no bonde, o baiano voltou a atacar Nabuco, e ainda aludiu ao boato de que o famoso abolicionista teria vendido os escravos que recebeu de herança, em vez de libertá-los, como era de se esperar. A provável difamação deu origem a uma polêmica nos jornais. Seabra disse que apenas se referiu ao boato, do qual não tinha comprovação, em defesa de Machado Portela. (CASTRO, 1990) Os dados sugerem que sua ligação com esse chefe conservador vinha desde os tempos de estudante. Foi a Machado Portela que Seabra recorreu quando, em seu famoso concurso para professor, não sabia onde encontrar a bibliografia para determinada questão. $\mathrm{O}$ conselheiro emprestou-1he um livro, o qual o candidato estudou com afinco. Segundo o próprio Seabra, na entrevista à revista Diretrizes (1942), foi graças a essa ajuda que ele conseguiu 
superar os concorrentes. Era esperado, então, que ele defendesse Machado Portela de quaisquer acusações.

O abolicionismo de Seabra era restrito aos limites estabelecidos por seus amigos conservadores, que condicionavam a abolição à indenização dos proprietários. Essa postura the rendeu nova polêmica, em Salvador, em janeiro de 1885. O professor de Direito proferiu duas "conferências abolicionistas" na terra natal, defendendo a indenização dos senhores. Além de receber muitos apartes da plateia - coisa que não intimidava Seabra, já que ele apreciava muito uma polêmica - as conferências deram origem a um debate nos jornais. No Diário de Notícias, Raimundo Bizarria chamou o palestrante de "pseudoabolicionista". (CASTRO, 1990) De fato, as ações de Seabra trazem todos os indícios de um abolicionismo tardio e de conveniência, adotado no momento em que a causa da escravidão perdera todos os resquícios de legitimidade.

Mas a questão que nos parece fundamental e que emerge das referências disponíveis, é que, diferentemente de Rui, Seabra não se engajou na onda da crítica ao regime. Ao contrário, ele buscou sempre a inserção no sistema. Por isso, não pode ser considerado um integrante da Geração de 1870, como movimento político-intelectual.

Essa hipótese se fortalece quando se observa a relação de Seabra com os elementos que se consideravam os "renovadores" dentro da faculdade de Direito pernambucana. Como se sabe, ali estava um dos principais núcleos de difusão das novas doutrinas estrangeiras: o grupo que ficou conhecido como a Escola de Recife, liderado por Tobias Barreto e Silvio Romero9. Seabra não só não se integrou ao grupo dos "avançados”, como também se confrontou diversas vezes com eles, em questões internas da faculdade.

\footnotetext{
9 O nome Escola de Recife, apesar de consagrado, é controverso, já que esse grupo nunca se configurou realmente em uma "escola", com programa ou discípulos definidos. Ângela Alonso (2002, p. 134) chega a afirmar que a expressão, inventada por Silvio Romero, "descreve quase exclusivamente as façanhas do próprio Romero e a amplificação dos acanhados feitos de seu 'mestre', Tobias Barreto". Sem entrar no mérito dos feitos de Tobias Barreto e Silvio Romero, o fato é que havia um grupo de alunos e professores articulado em torno deles. Mesmo que o grupo não possa ser considerado uma "escola" intelectual, era um grupo atuante na política interna da faculdade, com o qual Seabra se confrontou.
} 
Em 1882, quando Tobias Barreto disputou uma vaga de professor substituto com o cunhado de Seabra, José Augusto de Freitas, o professor baiano entrou em campanha em favor do parente. Chegou a escrever ao visconde de Paranaguá para, a pretexto de parabenizá-lo pela ascensão à presidência do Conselho de Ministros, fazer-lhe o seguinte pedido enviesado:

Quisera aqui poder interceder ante V. Exa. por meu cunhado, que entrou em concurso aqui na Faculdade e, apesar da incruenta guerra, foi classificado em $2^{\circ}$ lugar [...], estando em $1^{\circ}$ um homem que, se pode competir com ele em talento e ilustração, todavia não o pode fazer sob o ponto de vista da moralidade, critério e bom senso, mas não devo fazê-lo, atendendo ao fim único e exclusivo desta, cordialmente cumprimentar V. Exa. (1882 apud CASTRO, 1990)

Os esforços de Seabra não deram resultado e Tobias Barreto foi nomeado professor. Um novo confronto ocorreu em 1883, a propósito da escolha de um representante acadêmico para uma manifestação abolicionista. O escritor Graça Aranha, partidário do grupo de Tobias, comentou o episódio da seguinte forma, em seu livro de memórias:

O nosso candidato, o poeta Martins Junior, era combatido pelo candidato baiano Filinto Bastos. Este sustentado pelo lente Seabra, naquele tempo o mais desenfreado reacionário dos professores. Nós, os avançados, o detestávamos, e ele não nos poupava. Na eleição tão disputada, a urna foi fraudada. Seguiu-se um tumulto diabólico [...]. Foi redigido um protesto contra a fraude, que se atribuía à inspiração do então jovem Seabra. (1931 apud PAIM, 1966, p. 60-61)

A expressão "desenfreado reacionário" deve ser entendida à luz de seu sentido literal: Seabra estava na reação aos que se consideravam avançados na faculdade. Mas, o mais revelador dos episódios mencionados parece ser que, mais do que o debate abstrato de qualquer doutrina, interessava a Seabra o fazer concreto da política, tanto externa à facul-

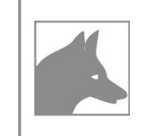


dade quanto interna. Foi para influir na eleição de um aluno baiano que ele, professor, se envolveu na disputa acadêmica a ponto de ser acusado de fraudar uma urna. Se o grupo de Graça Aranha o detestava, outros estudantes tinham dele uma opinião muito favorável.

Voltando às referências culturais, os dados sugerem que nem Seabra nem Rui estavam entre os partidários mais entusiasmados das "novas ideias", como o positivismo de Comte e as teorias de fundo biológico/ racial. Rui permaneceu, como se viu, atrelado ao liberalismo imperial, em sua vertente mais progressista. Seabra, ao que tudo indica, também compartilhava do credo liberal, na linha conservadora. Apesar disso, os dois baianos não deixaram de incorporar alguns aspectos dessas doutrinas, pois elas penetraram no cerne do pensamento compartilhado por indivíduos de sua posição social, formação e geração. Essas inovações se articularam a pontos herdados da tradição imperial, como o apego à ordem, o senso de hierarquia e uma visão da política como território do debate entre "chefes", entre os senhores-cidadãos, aos quais o restante da população deveria se vincular por relações variadas de dependência. (FERNANDEs, 2002)

A ênfase nas ideias de progresso e de civilização era o ponto principal desse novo panorama. Como assinala Lília Schwarcz (1996, p. 82), "ninguém duvidava do progresso - de um progresso linear e determinado - assim como não se questionava a ideia de que o único modelo de civilização era aquele experimentado pelo Ocidente". A existência de uma linha evolutiva única, encimada pela civilização europeia, servia de argumento para o imperialismo na África e na Ásia, fortemente impulsionado nas últimas décadas do século XIX. Sob a justificativa de levar a civilização a povos bárbaros, supostamente infantis na escala do desenvolvimento humano, o avanço neocolonialista travestia-se de missão humanitária. (SILVEIRA, 1999)

Os grupos dominantes da sociedade brasileira perseguiam a civilização com todas as forças do corpo e da alma. Quem, afinal, desejava ser classificado entre os bárbaros? O país apresentava, porém, uma miríade 
de aspectos incompatíveis com o modelo de civilização almejado. Havia a questão da raça, que se imaginava "corrigir" através da imigração. Era preciso também sanear e embelezar as cidades, criar transportes, comunicações e serviços urbanos (ferrovias, navegação a vapor, eletricidade, telégrafos, telefones, bondes, cinema), educar a população, melhorar os costumes, organizar instituições. Urgia modernizar, romper, abrir, destruir os vestígios da antiga colônia, para dar passagem ao novo, belo, arejado e salubre.

A ruptura, contudo, tinha seus limites. Para "progredir", era essencial manter a "ordem", como ensinava a divisa positivista inscrita na bandeira republicana. A preocupação com a estabilidade social era um denominador comum da elite brasileira, no momento em que as velhas regulações da sociedade escravista já não se aplicavam.

Um exemplo: quando a abolição foi finalmente transformada em lei, em 13 de maio de 1888, apenas nove parlamentares votaram contra, enquanto oitenta e três foram favoráveis. Naquela votação, que todos sabiam ser de grande visibilidade histórica, um dos favoráveis foi o deputado baiano José Marcelino de Sousa, do Partido Conservador, futuro governador da Bahia. Apenas quatro meses depois, o mesmo deputado já criticava os meios “bruscos, rápidos einstantâneos" pelosquais se feza aboliçãono Brasil e fazia a pergunta fundamental: "Dantes, tínhamos a autoridade do senhor sobre o escravo, era a sujeição que determinava o trabalho; mas, hoje, qual a lei que obriga os libertos e proletários ao trabalho?". (sousA, 1949, p. 19)

Essa era uma das questões que homens como Rui e Seabra teriam que enfrentar na República. Antes de tratar da dinâmica republicana, no entanto, será preciso tecer breves considerações sobre a forma como os dois baianos realizaram sua inserção na política nacional, e como isso se relaciona às suas estratégias posteriores de atuação. 


\section{Estratégias de atuação política}

Rui Barbosa atuou como deputado geral, no Império, por apenas seis anos. A partir de 1884, perdeu todas as eleições que disputou. Apesar disso, em 1889, não somente foi cotado para ser ministro como, após a proclamação da República, era considerado um dos principais homens do novo regime. Como se explica a discrepância entre seu desempenho partidário declinante e sua crescente relevância política?

A explicação reside no fato de que a tribuna parlamentar não era o único espaço de debate político na sociedade brasileira das últimas décadas do Império. Havia a rua, os cafés, os teatros, as associações e, principalmente, a imprensa. (MELLO, 2007) Embora dirigida aos letrados, que constituíam uma parcela reduzida da população, a imprensa conseguia atingir um público bem mais amplo do que o círculo dos conchavos partidários. Para esse público, especialmente para os que não vinham encontrando espaços para ascender no sistema imperial, quanto mais crítica a postura de Rui, quanto mais incisivos seus ataques, mais interessante e destacado ele se tornava. Sua palavra começou a ganhar, assim, um valor diferente. Ele já não era apenas mais um político tentando fazer carreira na Corte. Era Rui Barbosa, o mestre do verbo, manejando com destreza as armas cortantes da retórica e da erudição.

Foi através do jornalismo, portanto, que Rui conseguiu converter a marginalização relativa a que estava submetido em um trampolim para alcançar novos horizontes na política: arriscava, assim, seus primeiros volteios de "águia" em voo solo.

Diferente, quase oposto, foi o caminho traçado por Seabra. Como Rui, ele era desprovido de recursos financeiros e não vinha de família tradicional. Precisava, igualmente, do apoio de chefes estabelecidos. Mas, sem dispor, como Rui, de uma porta aberta no Partido Liberal, Seabra tentou estabelecer relações com elementos prestigiosos do partido que detinha o poder. Sua estratégia de inserção, portanto, foi tentar encontrar 
espaços por dentro do sistema. Apesar de não ter conseguido sequer um mandato em todo o Império, não se pode dizer que ele tenha fracassado. Afinal, Seabra obteve a cátedra em Recife, posição de muito prestígio, além de um emprego de promotor. Com a instalação da República, soube ser flexível e ágil para conquistar um mandato em meio ao atordoamento que parece ter tomado conta de parte da elite baiana. Dava mostras, assim, de grande capacidade de compreender a dinâmica do poder, como jovem "raposa” política que era.

Essas diferentes estratégias iniciais repercutiram no desenvolvimento político posterior dos dois baianos. No caso de Rui, o impacto de sua palavra jornalística, estendido mais tarde à tribuna do Senado e aos meios jurídicos, favoreceu o surgimento de uma relação especial com os dirigentes baianos na República: uma relação baseada no respeito, na reverência e, às vezes, no temor.

O marco inicial dessa relação foi a proclamação da República, que assinalou a ascensão definitiva de Rui ao primeiro patamar da política nacional. Além de ministro da Fazenda, ele era vice-chefe do governo provisório, com influência notória sobre o chefe, marechal Deodoro da Fonseca. Foi um dos principais formuladores da primeira Constituição republicana e até sugeriu o novo nome oficial do país: Estados Unidos do Brasil. Por influência de Rui, o governo da Bahia foi entregue a Manuel Vitorino, seu antigo colega de Partido Liberal, no lugar do republicano histórico Virgílio Damásio, que já havia assumido o cargo. (SAMPAIO, 1998, p. 59)

Desde esses primeiros momentos, firmou-se uma espécie de entendimento tácito entre Rui e os governantes da Bahia republicana - um entendimento que teve seus momentos de tensão, mas que era geralmente respeitado, ao menos até a ascensão de Seabra. Baseava-se, por um lado, no reconhecimento da autoridade de Rui no plano nacional e na renovação de seu mandato no Senado Federal, sua principal tribuna. Em troca, o senador não interferia na política estadual de forma ostensiva, deixando espaço para os governadores conduzirem seus arranjos.

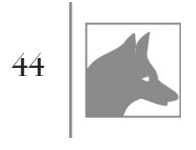


Os dirigentes baianos reconheciam o brilho do conterrâneo e louvavam suas qualidades, o que também era uma forma de mantê-lo distante da Bahia. Seus poucos afilhados políticos eram incluídos nos partidos governistas, não configurando uma corrente à parte. Rui não tinha nem jornal próprio na Bahia, pré-requisito básico para todo agrupamento político do período. Apesar disso, sua ascendência era grande.

A influência de Rui na política baiana ocorria, basicamente, de duas formas. A primeira era a forma comum: o aproveitamento de sua inserção no primeiro escalão da política nacional, com tudo que isso significava em termos de influência, benefícios, cargos e vantagens. Como político baiano de destaque nacional, era esperado que ele, não só defendesse projetos de interesse da Bahia, ou dos seus aliados na Bahia, como tivesse condições de beneficiar "amigos" baianos na obtenção de vantagens. Era o mundo da "pequena política”, que se explorará com mais detalhes no segundo capítulo. Por ora, basta assinalar que Rui era o único baiano com prestígio comparável ao da “constelação de estadistas" baianos do Império. Como estrela solitária no céu da República, ele se tornou um interlocutor fundamental da elite baiana junto ao poder central. Não por acaso, partiram da Bahia mais de 30\% do total de pedidos enviados a Rui quando ministro da Fazenda. (CARVALHO, 2000)

A segunda forma de influência de Rui na política baiana era bem menos comum - na verdade, era única. Derivava do peso atribuído nacionalmente à sua palavra, que inibia os dirigentes da política baiana de tomarem qualquer atitude que o contrariasse. A questão é que, mesmo em seus longos períodos de oposição ao governo federal, ele atuava no espaço público com grande visibilidade, nos jornais, no Senado e nos tribunais. Para os políticos dominantes na Bahia, era importante ter Rui como aliado, pois ele era um adversário a temer. O governador Luís Viana expressou claramente esse sentimento, em 1896, ao então correligionário Severino Vieira, que tentava convencê-lo a não renovar o mandato de Rui no Senado, visando agradar ao governo federal. Escreveu Luís Viana: 
O Rui é um baiano, um brasileiro, tão eminente que, sem grave responsabilidade, não poderíamos assumir o compromisso de excluí-lo da representação do país [...].

Receiam o Rui? Ele nos faria mais mal fora do Parlamento. Não se lembra do que se deu por ocasião da exclusão acintosa dele do Ministério Ouro Preto? (VIANA FILHO, 2008, p. 382-383)

Luís Viana lembrava que, em 1889, contrariado em seus planos pelo visconde de Ouro Preto, Rui assestou suas baterias contra o Império, em campanha jornalística memorável, que contribuiu para criar o clima favorável à derrubada do regime. Qual poderia ser o efeito de seu verbo enfurecido contra o grupo que controlava o governo da Bahia? O governador sabia que, mesmo sem estar no auge da popularidade e da força naquele momento, Rui ainda podia contar com a imediata repercussão de suas palavras em todo o país.

Em 1896, com efeito, a situação política de Rui não estava tão lisonjeira como nos primeiros anos da República. Pesava contra ele a memória de sua atuação como ministro da Fazenda, que resultou em forte descontrole inflacionário. Não se discutirá aqui a política econômica que deu origem ao famoso "encilhamento". Basta registrar que, ao sair do ministério, em janeiro de 1891, em meio à demissão coletiva dos ministros de Deodoro, Rui carregava uma marca que jamais o deixaria: a do ministro que provocou o maior surto especulativo vivido no país até então. Além disso, os adversários lançavam suspeitas sobre seu enriquecimento, apontando como evidência de sua "vida de nababo" até o brilho dos vestidos de Maria Augusta, sua esposa. (GONÇALVES, 2000b, p. 78-79; BARBOSA, v. 20, 1893, t. 1, p. 43)

Após a saída do ministério, as relações de Rui com o poder central ficaram tensas. Em 3 de novembro de 1891, ele criticou o marechal Deodoro pelo fechamento do Congresso e, vinte dias depois, apoiou o contragolpe dado pelo vice-presidente Floriano Peixoto. Mas o novo presidente decidiu derrubar todos os governadores deodoristas, inclusive José Gonçalves,

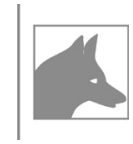


da Bahia, aliado de Rui. O senador baiano não podia aceitar essa interferência. Inicialmente, ele pediu a Floriano que mantivesse seu aliado. Não sendo atendido, partiu para uma feroz oposição. Mostrava-se aí, claramente, a importância da política baiana na atuação nacional de Rui Barbosa. Ninguém podia interferir nos negócios da Bahia sem esperar uma reação sua. (GONÇALVES, 2000b, p. 80)

O Brasil vivia um período de turbulência política. Em abril de 1892, Floriano Peixoto recebeu o "manifesto dos 13 generais", contra sua permanência no cargo. Em represália, os generais foram reformados e foi decretado o estado de sítio. O governo também mandou prender e desterrar manifestantes civis, incluindo alguns parlamentares que participaram de uma manifestação pró-Deodoro. O senador Rui entrou com habeas corpus em favor dos desterrados. Ao descrever o infortúnio dos presos, na peça jurídica, narrou a seguinte cena:

Outro desterrado, senhores juízes, membro do Congresso, lente de uma faculdade jurídica, passou por convícios de tal ordem, que as lágrimas lhe arrasavam os olhos, e a mão, que não podia levantar-se contra os baldoadores seguros da superioridade material, mostrava, como a mais irrefragável das respostas ao insulto, uma cédula de vinte mil réis, soma total da riqueza com que ele partia para o desterro indefinido. (BARBOSA, 1892, v. 19, t. 3)

O homem que partia para o desterro em lágrimas, brandindo uma nota de dinheiro no ar, era o deputado federal J. J. Seabra, que também vinha se batendo contra o florianismo. Nessa época, os dois baianos combatiam lado a lado, e tinham uma relação amistosa, embora não de igual para igual. Era marcante a diferença de importância política entre os dois, que transparece no tom subserviente das cartas de Seabra do período, guardadas no arquivo de Rui (ARB). Diante do prestígio do seu “eminente mestre", Seabra era apenas um iniciante. Mas, um iniciante que não perdia oportunidades de chamar atenção no cenário nacional. 
De fato, Seabra estreou na política com todo o ímpeto que o caracterizava. $\mathrm{Na}$ sessão solene de instalação da primeira Assembleia Constituinte republicana, foi o primeiro deputado a solicitar a palavra. Manifestou-se para pedir a nomeação de uma comissão para cumprimentar o marechal Deodoro da Fonseca, chefe do governo provisório. A proposta foi aprovada por unanimidade, pois votar contra seria uma desconsideração ostensiva ao generalíssimo, embora já existisse uma oposição articulada em torno do vice, Floriano Peixoto. O episódio é indicativo da estratégia que Seabra adotaria repetidamente na República: assumir posições destacadas, através dos seus recursos de oratória e da disposição de se expor sem restrições, firmar alianças nacionais e, através disso, fortalecer sua posição na Bahia. Era uma atuação por dentro do poder nacional e, simultaneamente, a partir de fora, em relação à política baiana.

Sua aproximação do marechal Deodoro foi logo recompensada. Ainda em 1891, aos 36 anos de idade, Seabra foi nomeado diretor da faculdade de Direito de Recife. Chegou a tomar posse, mas ficou pouco tempo no cargo. Suas aspirações acadêmicas já haviam passado definitivamente ao segundo plano, em relação à política.

Como deputado federal, Seabra apoiou os atos do governo provisório, inclusive a gestão de Rui no ministério da Fazenda e o plano do encilhamento. Aplaudiu também outra medida polêmica adotada pelo ministro Rui: a queima de documentos ligados à escravidão, sob o argumento de evitar pedidos de indenização pelos senhores - exatamente o contrário do que Seabra pregou em sua atividade como "abolicionista”. O deputado não somente votou a favor da queima, como propôs ao Congresso uma moção de congratulação com o "patriótico Governo Provisório, que acabou de uma vez para sempre com aquilo que era nossa vergonha, a página negra da história do Brasil”. A moção foi aprovada, com 83 assinaturas. (BRASIL, 1890/1891, p. 193)

Como deodorista entusiasmado, Seabra se engajou na oposição a Floriano Peixoto, quando este assumiu o poder. Em 1892, participou 
da manifestação já mencionada, foi preso e desterrado em uma região inóspita da Amazônia. Não se tratará aqui das aventuras de Seabra no desterro, contadas por seus biógrafos: suas narrativas incluem conspirações de fuga, taperas perdidas na selva, sonhos premonitórios e um episódio de malária que quase matou o deputado baiano. Ao retornar ao Rio de Janeiro, ele continuou na oposição a Floriano Peixoto na Câmara. Naquele momento, portanto, Rui e Seabra ainda atuavam do mesmo lado no cenário nacional. Os dois sofriam as consequências de ser oposição, em um período de grande tensão política.

Após a defesa que fez dos envolvidos na Revolta da Armada, em setembro de 1893, Rui Barbosa foi perseguido pelo florianismo e teve que deixar o país. Depois de idas e vindas, acabou se exilando na Inglaterra. Seabra também se envolveu com o movimento, chegando a embarcar no navio Aquidabã com os rebeldes. Com o fracasso da revolta, refugiou-se no Uruguai. Ao regressarem do exílio, tanto Rui como Seabra teriam que se esforçar para recuperar seu espaço no jogo de poder baiano e nacional.

Esse foi, provavelmente, o momento politicamente mais difícil para Rui na República. Quando seu mandato no Senado expirou, em 1896, alguns dirigentes da Bahia pensaram em não renová-lo, para agradar a Prudente de Morais, sucessor de Floriano. Os aliados do presidente desejavam eliminar Rui do Senado, para evitar que ele se tornasse, mais uma vez, um opositor incômodo. Foram essas as circunstâncias da carta de Severino Vieira a Luís Viana, já citada. Mas, o medo de desagradar Rui foi mais forte do que a vontade de agradar ao presidente. Luís Viana assegurou a eleição de Rui para o Senado, para um novo mandato de oito anos.

No caso de Seabra, a situação era mais difícil. Sua expressão política era infinitamente menor. Ao regressar do exílio, seu primeiro mandato de deputado federal já havia acabado, e ele teve que reassumir a cátedra em Recife. Nas eleições de 1896, buscou apoios para retornar ao Congresso. Mas, ao contrário de Rui, ele não contava com a boa vontade de Luís Viana. Conforme Dunshee de Abranches (1973 apud sanTos, E., 
1990, p. 27-28), o governador teria dito que a candidatura de Seabra era repelida pelos baianos e que, "só em caso de desespero", o partido dominante adotaria o nome "desse fazedor de conspirações e de revoltas". Como se vê, tanto Rui como Seabra haviam ficado estigmatizados pela atuação na oposição. A exclusão de Seabra também atendia a pedidos do governo federal, especialmente do deputado paulista Francisco Glicério, que era muito influente junto ao novo presidente, Prudente de Morais.

Para furar essa barreira, Seabra recorreu ao tio, almirante Manuel Alves Barbosa, que havia sido designado ministro da Marinha, ao próprio senador Rui Barbosa e a Manuel Vitorino, que havia sido eleito vice-presidente da República. O apoio deste último parece ter sido decisivo. Segundo um relato do juiz Paulo Martins Fontes, em carta ao barão de Jeremoabo (SAMPAIO, 1999, p. 126-127), Vitorino praticamente impôs o nome de Seabra na chapa governista para a Câmara, ao mesmo tempo em que tentava remover Rui do Senado. No tocante a Rui, essa versão contradiz as informações de Luís Viana Filho (2008, p. 380), que informa que Manuel Vitorino defendeu essa candidatura ao lado de seu pai, Luís Viana. Os dois teriam resistido às pressões anti-Rui de Severino Vieira, Prudente de Morais e Francisco Glicério.

É difícil saber que interesse tinha Manuel Vitorino na eleição de Seabra. Pode-se imaginar que os dois tenham firmado algum acordo sobre a atuação do deputado na defesa do governo. Quanto a Rui, tanto o apoio quanto a rejeição de Vitorino são verossímeis. O vice-presidente era amigo de Rui desde o Partido Liberal monárquico. Em 1893, em uma conferência na Bahia, os dois se saudaram como “irmãos”. (BARBOSA, v. 20, 1893, t. 1, p. 23) Por outro lado, como membro destacado do novo governo, Manuel Vitorino pode ter buscado contribuir discretamente para a eliminação de um opositor, atendendo ao que desejavam o presidente e seus aliados.

Eleitos, como se viu, com grandes dificuldades, Rui e Seabra seguiram em suas atividades políticas. Rui, como esperado, partiu para a oposição a Prudente de Morais, não somente no Senado, mas também na 
imprensa e nos tribunais, advogando em causas contra os interesses do governo. (GONÇALVES, 2000b, p. 96-97) Manteve essa postura também em relação ao presidente seguinte, Campos Sales. Em 1898, fundou um jornal, $A$ Imprensa, que se tornou sua tribuna preferencial para atacar o governo, mas o veículo teve dificuldades financeiras e fechou. Apesar do sucesso como jornalista, da repercussão das suas críticas, a vida na oposição era muito difícil. Na Bahia, a situação de Rui permanecia a mesma, embora sua influência provavelmente tenha diminuído com a ascensão de Severino Vieira ao governo em 1900.

Quanto a Seabra, o retorno ao Congresso, em 1896, foi a oportunidade de voltar a se agarrar às engrenagens do poder, apoiando-se nos elementos certos para subir. Eleito contra a vontade do presidente, ele conseguiu retomar a estratégia de se destacar como governista, articulando-se ao grupo que pretendia reduzir a influência de Francisco Glicério no governo. Em maio de 1897, propôs ao Congresso uma moção de congratulações a Prudente pela repressão da revolta da Escola Militar, ocorrida naquele mês. A chamada "moção Seabra" - que teve grande repercussão e ajudou a projetar o nome do deputado baiano - foi uma manobra para revelar as conexões de Glicério com os rebeldes. Sem poder subscrever a moção, pois estava realmente ligado aos jacobinos da Escola Militar, Francisco Glicério teve que deixar a liderança do governo. Foi uma vitória do grupo de Seabra, que ampliou seu espaço na base governista.

As relações de Seabra com Prudente de Morais se estreitaram quando o deputado baiano atuou como advogado da família do marechal Bittencourt, ministro da Guerra, morto ao defender o presidente no atentado de novembro de 1897. Seabra acusou os supostos mandantes do crime, inclusive o vice-presidente Manuel Vitorino, que teria se envolvido com os conspiradores para permanecer na Presidência (ele havia assumido o cargo entre novembro de 1896 e março de 1897 quando Prudente se afastara por problemas de saúde). Articulado ao grupo prudentista, Seabra não hesitou em acusar Manuel Vitorino, a quem devia 
sua eleição para o Congresso. Sob o pseudônimo Caneca (herança da vivência pernambucana), mandou publicar artigos na Gazeta de Notícias (RJ), atacando o vice-presidente e o juiz Afonso de Miranda, responsável pelo caso, que excluiu Vitorino do rol de acusados. $\mathrm{O}$ tom dos artigos era de confrontação direta:

Que consciência reta não se achará alarmada e sobressaltada diante do desplante com que o Sr. Afonso de Miranda teve a coragem de vir, lampeiro, afirmar ao Brasil e ao mundo que não encontrou no processo, inquérito e formação de culpa, indícios veementes da criminalidade do homem [Manuel Vitorino] para quem seus amigos já cogitaram de requerer um habeas corpus preventivo, de um homem apontado pela opinião pública como conspirador e co-autor do indigno e infame atentado de 5 de novembro?! [...]

Desde o dia em que o sr. Manuel Vitorino tomou posse do cargo de presidente da República, no impedimento, por moléstia, do dr. Prudente de Morais, que conspira contra o presidente a fim de empolgar o poder, não escolhendo os meios, de modo a concordar com a eliminação dele pela garrucha de Marcelino Bispo. (CANECA, 1898, p. VI-VII)

Seabra prosseguiu na linha entusiasmadamente governista durante o governo de Campos Sales. O presidente, no início do mandato, não simpatizava com o deputado baiano, considerando-o "turbulento, agitador e ignorantão”. (SANTOS, E., 1990, p. 30-32) Pouco depois, ele já assumia o importante cargo delíder do governo na Câmara, destacando-se na defesa do empréstimo do tipo fundingloan. Foi reeleito em 1899, sem dificuldades. Com apoio de Campos Sales, Seabra conseguiu ser nomeado ministro da Justiça e Negócios Interiores, no mandato do novo presidente Rodrigues Alves, que se iniciou em 1902. O ministério foi a porta de entrada para Seabra ingressar no primeiro escalão da política brasileira, e o impulsionador de sua primeira tentativa de estabelecer um projeto de domínio político da Bahia. 
Coincidentemente, a gestão de Rodrigues Alves também assinalou uma importante inflexão na trajetória de Rui Barbosa. Desde a saída do ministério de Deodoro, ele havia feito oposição a todos os presidentes republicanos. O próprio nome de Rui já estava simbolicamente vinculado à ideia de oposição, de crítica, como assinala Gonçalves (2000b, p. 107). Porém, a continuação dessa atitude vinha colocando em risco sua sobrevivência política. Até mesmo o mandato de senador pela Bahia já havia sido ameaçado, e Rui não pretendia resumir a ele sua atividade. Suas ações indicam que ele desejava atingir a presidência da República, onde poderia colocar suas ideias em prática. A atitude de eterno opositor tornaria esse projeto inviável. Por tudo isso, em 1902, Rui decidiu apoiar a presidência de Rodrigues Alves, seu antigo colega de faculdade. A adesão foi formalizada em um "verdadeiro ritual de passagem", descrito por João Felipe Gonçalves:

O ritual se deu em 22 de abril de 1903, quando Rui presidiu um banquete oferecido a Pinheiro Machado, vice-presidente do Senado e agente fundamental do poder oligárquico. Também tocou a Rui fazer o brinde de honra a Rodrigues Alves, instituindo ritualmente sua adesão ao governo. Seu discurso reforçava a nova posição: afirmou que os mesmos 'princípios de liberdade e justiça, de legalidade e democracia' que tinham sustentado sua oposição levavam-no agora a apoiar o novo presidente. Rui dizia ver nele as promessas da 'recomposição moral do regime'. Por isso, assegurava: 'O meu apoio é como minha oposição: sem rodeios'. (GONÇALVES, 2000b, p. 107-108)

Ao lado de Pinheiro Machado, o senador baiano agora iria atuar também por dentro do regime, articulando as forças estaduais que sustentavam a República. Dentre essas forças, estava a de sua terra natal, então governada por Severino Vieira e prestes a sofrer as investidas do ministro Seabra. Esses dois elementos políticos ameaçavam atrapalhar a relação consagrada de Rui com o situacionismo baiano, justamente quando o senador precisava de aliados fiéis para seu projeto presidencial. Mas, para compreender 
como essas forças se conjugavam, será preciso olhar mais de perto como se processava a dinâmica política da Bahia republicana, o que também ajudará a entender outras características da atuação de Rui e Seabra. 